\title{
Systems and Tools for Supporting Farmers' Decisions Regarding the use of Agrochemicals in Poland
}

\author{
Arkadiusz PIWOWAR \\ Wrocław University of Economics, Wrocław, Poland \\ arkadiusz.piwowar@ue.wroc.pl
}

\begin{abstract}
Poland currently belongs to countries with a relatively high consumption of agrochemicals, in particular mineral fertilizers and chemical herbicides. From the perspective of environmental protection, as well as improving the efficiency of treatments using agrochemicals, it is essential for the farmer to have knowledge in order to make the right decisions. To meet these needs, Decision Support Systems, IT tools providing information and knowledge, supporting organizational and business decision-making activities are created. This paper presents the results of analyses of the use of these systems in Poland. The work also presents innovative decision support systems in the form of applications as well as statistical data on the current level of agrochemical consumption in Polish agriculture. According to the analyses, Polish farmers have access to many systems, including innovative ones. Statistical data shows that users of farms in Poland only to a small extent use the decision-making support of in the field of plant protection. in this respect, it is necessary to increase the activity of farmers in the search for knowledge from many different sources and to significantly increase its level and improve their skills.
\end{abstract}

Keywords: Mineral Fertilization, Use of Plant Protection Products, Decision Support Systems, Decision Support Tools, Poland.

\section{$1 \quad$ Introduction}

In many areas of the economy, decision support systems have been used for more than 40 years and they have been present in the agricultural sector for over 30 years. During this period, decision support systems in agriculture went through the phases of unbelief, euphoria and disappointment, to the stage of maturity with realistic, potential impact [10]. There is also no doubt that farmers need more and more information to develop task plans that meet economic and environmental goals. The scope of input data for analyses performed on a farm is very large, and the complexity of problems at the interface between economy and environment in agriculture causes problems with verification of information and selection of optimal solutions from the economic and ecological point of view. Decision support systems in agriculture are a factor contributing to the implementation of a viable farming economy with a lower negative impact on the environment. In particular, it is important to provide farmers with up-todate and relevant information [8]. To be applied in practice, the designed systems must 
be assessed by farmers as useful tools for accessing information and advice in agricultural systems. Promptness and reliability of the systems are also important.

Decision support systems are an important factor in improving organizational and business processes in farm management, especially in the area of improving productivity and environmental performance [15, 17]. For farmers and agricultural advisors, support systems and tools can facilitate effective management of an agricultural holding through effective data recording, analysing it and generating practical recommendations [16]. This applies, among others, to the use of agrochemicals, including plant protection products and mineral fertilizers. Currently, systems in this area are designed and modernized in many countries. For example, the Swedish project for the development of the agricultural decision support system (AgriDSS) for nitrogen fertilization is currently being carried out [9]. Activities in this area are undertaken in most countries by both public institutions and business entities.

The main purpose of this work is to show the degree of use of Decision Support Systems in the area of fertilization and plant protection in Poland. In addition, the work presents, i.a. innovative decision support systems in the form of applications, as well as statistical data on the current level of fertilization and pesticide use in Poland.

\section{Methods and Sources of Materials}

The article uses primary and secondary sources of information. In the field of primary sources, the results of a survey conducted by the author of work among 431 farms in Poland (from dolnośląskie and opolskie voivodeships with relatively high consumption of agrochemicals in Poland) were presented, in which pesticides were used in 20102015. A random selection was used. Empirical research was carried out in cooperation with Agricultural Advisory Centres. The research was representative in nature. Secondary sources of information, apart from literature on the subject, included also statistical data published by the Central Statistical Office (GUS). Due to the range of data available in the statistical sources, particular attention was paid to the area of pesticide use. Among the research methods used, the questionnaire method and market observation should be mentioned. All the considerations were based on extensive factual materials coming both from primary sources (surveys) and secondary ones.

\section{Consumption of Agrochemicals in Poland and Decision Support Systems Used in this Field}

According to the GUS data, in the 2016/2017 marketing year, fertilizer consumption amounted to $140.4 \mathrm{~kg} \mathrm{NPK} /$ ha agricultural land, i.e. $5.6 \%$ more than in the $2015 / 16$ season. In international statistics, the level of fertilizer consumption in Poland in the 2015/16 season was the third highest in the European Union (after Belgium/Luxembourg and Germany, and before the Netherlands and the Czech Republic). In some regions of Poland (mainly in the kujawsko-pomorskie, opolskie and dolnośląskie voivodeships) the applied fertilizers exceed the average level of 
consumption in the countries with the highest level of fertilization in European Union [14]. The fertilizer use structure in Poland is dominated by Nitrogen fertilizers (in the $2016 / 17$ season they constituted $56.1 \%$ of total consumption) [19]. It is worth emphasizing that in Poland there is significant regional differentiation in the level of fertilization, which is related to the variability of the crop structure, applied technologies and agricultural techniques (Fig. 1).

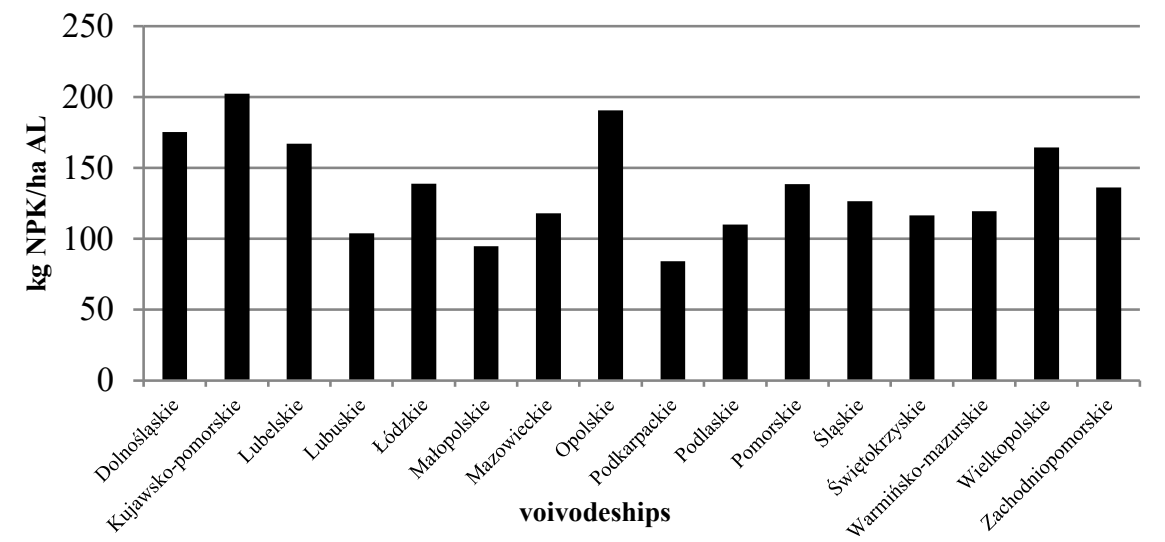

Fig. 1. Level of mineral fertilization (in terms of pure component) in Poland in farming year 2016/2017 [4].

According to GUS data, in two voivodeships the fertilization level was very high in the 2016/2017 season (in the Opole voivodeship it amounted to $190.7 \mathrm{~kg} \mathrm{NPK} / \mathrm{ha}$ of agricultural land, and in the Zachodniopomorskie voivodeship it was $202.5 \mathrm{~kg}$ $\mathrm{NPK} / \mathrm{ha}$ ). The lowest level of fertilization was recorded in the Małopolskie voivodeship (94.9 kg NPK / ha of agricultural land).

Considering the consumption of plant protection products, Poland is not a leader in the level of their consumption in Europe. The level of consumption of the active substance per 1 ha of arable land and permanent crops in Poland in 2016 amounted to $2.2 \mathrm{~kg}$. Considerably greater consumption is recorded in the Netherlands (over $9 \mathrm{~kg} /$ ha), Italy, Portugal, Germany and Slovakia. Nevertheless, in Poland a relatively large amount of herbicidal products is used and the level of their consumption is one of the highest in Europe [11,14]. According to GUS data, the scale of utilization of plant protection products in agricultural holdings in Poland is very large (Fig. 2). 


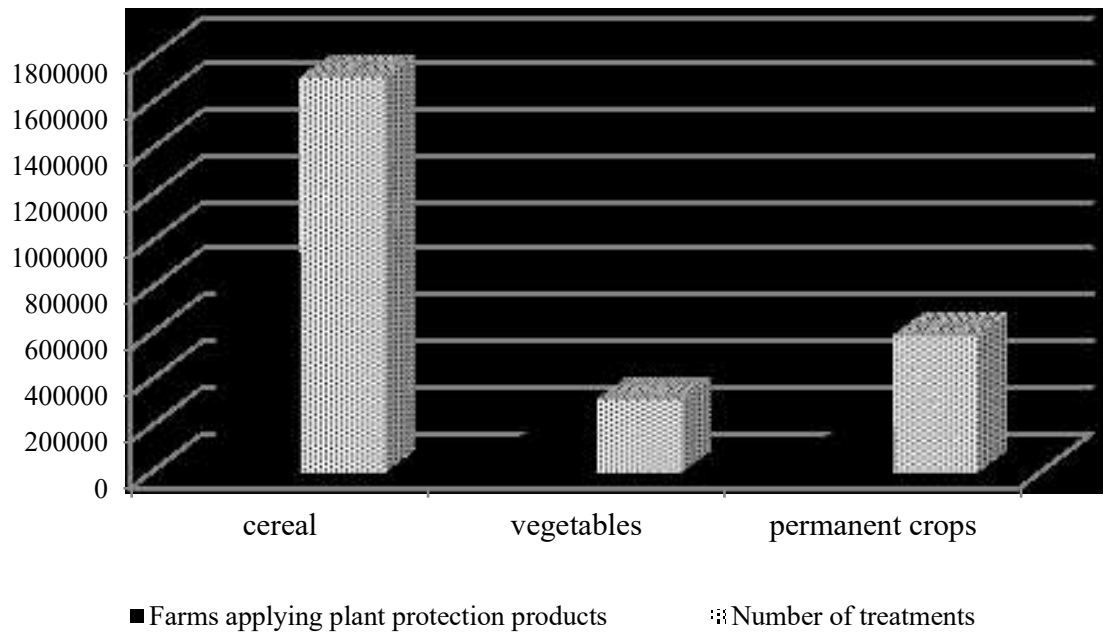

Fig. 2. Treatments with plant protection products conducted on farms in Poland in farming year 2016/2017 [4].

In Poland, since the beginning of the present decade, the consumption of plant protection products has been showing increasing tendency. These issues, especially in the economic and ecological context, are frequently the subject of analyses in the subject literature $[1,11,13,18,20]$.

Agro-technical treatments using agrochemicals, both fertilizers and pesticides, are difficult. Certainly, the difficulty does not consist in conducting the treatment itself (e.g. spraying) but in making a decision about the procedure and proper selection of technical means. As far as fertilization is concerned, knowledge of soil abundance and the ability of plants to take up nutrients is significant. . In turn, in terms of pesticides, the scale of pest risk is important, including the economic thresholds of harmfulness. It is also necessary to maintain optimal conditions during the procedure (temperature, wind strength, etc.). Due to all these factors, systems that will assist farmers in deciding whether to perform the procedure may be useful to them. The systems may also support the selection of a specific technical measure, the use of which is optimal in given economic and agri-environmental conditions.

According to statistical data, 339486 farms in Poland used support in decision making in the field of plant protection in the 2016/2017 marketing year. The most popular forms of support were personal consultancy and thresholds of economic harmfulness. The results of statistical surveys in this area are presented in tab. 1. It also shows the number of users benefiting from support in making plant protection decisions in individual voivodeships in Poland. Statistical sources do not contain information on systems in the field of fertilization; hence these systems are omitted in this part of the article. 
Table 1. Farmers using assistance in the making of decisions in plant protection in Poland in farming year 2016/2017 [4].

\begin{tabular}{|c|c|c|c|c|c|c|}
\hline Voivodships & Total & $\begin{array}{c}\text { Advisory } \\
\text { personnel }\end{array}$ & $\begin{array}{c}\text { Support } \\
\text { system in } \\
\text { plant } \\
\text { protection } \\
\text { decision }\end{array}$ & $\begin{array}{c}\text { Tresholds } \\
\text { of } \\
\text { economic } \\
\text { harm }\end{array}$ & $\begin{array}{l}\text { Monitoring } \\
\text { of harmful } \\
\text { organisms }\end{array}$ & $\begin{array}{c}\text { Other } \\
\text { sources } \\
\text { of } \\
\text { advisory }\end{array}$ \\
\hline & \multicolumn{6}{|c|}{ in absolute numbers } \\
\hline Dolnośląskie & 18078 & 11226 & 6844 & 10105 & 7023 & 10961 \\
\hline Kujawsko-pomorskie & 24371 & 16818 & 8434 & 15253 & 8592 & 12805 \\
\hline Lubelskie & 48452 & 31008 & 14669 & 27107 & 22868 & 25159 \\
\hline Lubuskie & 4849 & 2892 & 1646 & 2907 & 1388 & 3128 \\
\hline Łódzkie & 31282 & 19044 & 9499 & 17233 & 9067 & 17088 \\
\hline Małopolskie & 24438 & 17817 & 9470 & 14654 & 6904 & 13946 \\
\hline Mazowieckie & 45666 & 31547 & 15949 & 27012 & 16612 & 23114 \\
\hline Opolskie & 13658 & 10119 & 4353 & 5850 & 3892 & 7055 \\
\hline Podkarpackie & 20531 & 14606 & 5680 & 9933 & 6673 & 11301 \\
\hline Podlaskie & 11995 & 8393 & 3688 & 5167 & 2939 & 5454 \\
\hline Pomorskie & 10279 & 7854 & 3177 & 4711 & 3234 & 4509 \\
\hline Śląskie & 10040 & 7322 & 3215 & 5954 & 2601 & 3826 \\
\hline Świętokrzyskie & 18758 & 12024 & 6869 & 8756 & 5590 & 10001 \\
\hline Warmińsko-mazurskie & 10199 & 7293 & 3719 & 5852 & 4196 & 5512 \\
\hline Wielkopolskie & 39604 & 28594 & 16499 & 24153 & 13959 & 21875 \\
\hline Zachodniopomorskie & 7286 & 5083 & 2598 & 4089 & 2549 & 3825 \\
\hline Total & 339486 & 231640 & 116308 & 188737 & 118086 & 179559 \\
\hline
\end{tabular}

In terms of voivodships, the largest number of users using support services in the studied area was recorded in the Lubelskie, Mazowieckie and Wielkopolskie voivodeships. Against the background of the statistics presented above, the data from own research showing the sources of support in the studied area are presented below.

As presented in the research methodology, these are the results of analyses on a representative group of farmers from the Dolnośląskie and Opolskie voivodeships (ie voivodeships with a relatively high consumption of agrochemicals in Poland). According to own research, $71.5 \%$ of farmers declared the use of support systems. Fig. 3 presents decision support systems in the field of plant protection used by the respondents. 


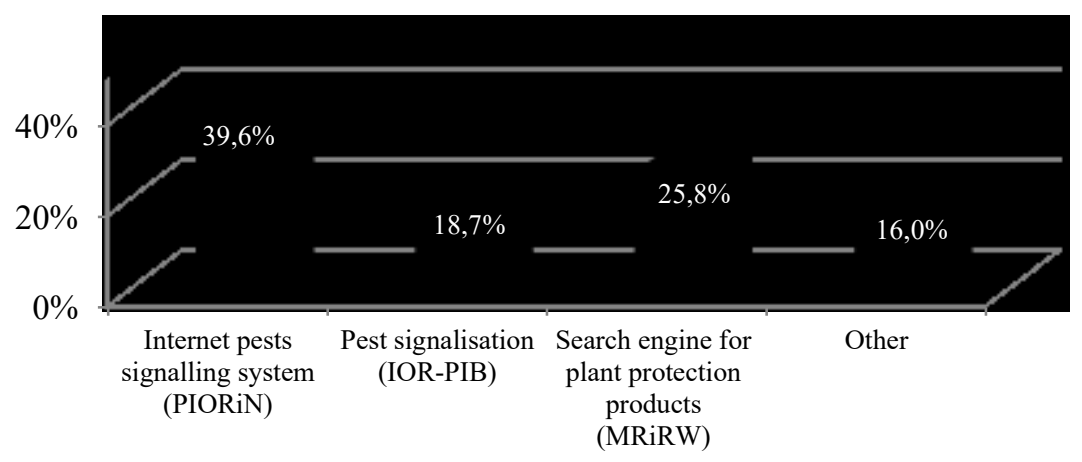

Fig. 3. Decision support systems in the field of plant protection used by the respondents.

According to the analyses, the most frequently mentioned system of support in the field of plant protection was the Internet pests signalling system (PIORiN), followed by the search engine for plant protection products (MRiRW) and pest signalisation (IOR-PIB). Responses in this area concerned individual advice provided by institutions (e.g. agricultural advisory centres) or economic entities selling agrochemicals. Most of the 308 farmers benefiting from support systems chose one system to support their decisions regarding the use of pesticides (Fig. 4).

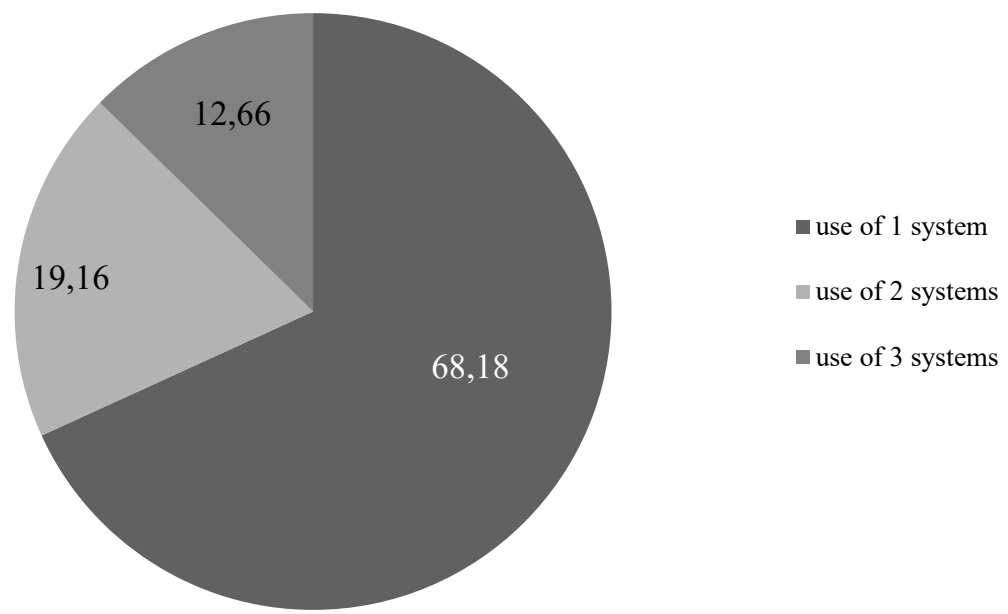

Fig. 4. Structure of users in terms of number of systems used on farms [\%].

According to analyses, relatively few farmers diversify sources of knowledge and use 2 or 3 systems simultaneously.

In the research, farmers mentioned systems popular in Poland, ie the Internet system of pests signalling (PIORiN), the search engine for plant protection products (MRiRW) and the signalling of pests (IOR-PIB). A description of these systems is presented in other works of the author of this article [11,12]. It is worth emphasizing here that innovative systems, described below, are currently being developed in Poland. 
According to analyzes, relatively few farmers diversify sources of knowledge and use 2 and 3 systems together.

The results of own studies of the author have clearly indicated that many farmers do not calculate the costs of plant protection treatments (both at the level of agricultural holdings and individual crops). The analyses of costs and profitability of protective treatments provide a basis for a rational use of the factors of production. There is also a problem of insufficient knowledge and professional skills of agricultural producers, while the importance of this problem may grow up along with the increase in the level of product innovation in the sphere of pesticides and technical equipment for their application. The ignorance in this scope may be accompanied by insufficient care of the quality of the protective treatments performed. This intensifies the educational and training needs [11]. ICTs are most useful to benefit education.

\section{Innovations in the Studied Area and their Potential}

As in other areas of human activity, also in the field of support systems' design, we deal with progress and the introduction of innovative solutions. Innovations concern, among other things, the sources of information, methods and ways of analysis and presentation of results. Some examples of such activities undertaken on the Polish market are presented below.

In the field of mineral fertilization, SatAgro web application is an innovative solution (Fig. 5). The application enables automatic processing of satellite data for monitoring individual arable fields and creating electronic dosing instructions for fertilizers (mainly nitrogenous). In the authors' assessments, the use of information on the crop growth phase and the suggested dose of fertilizer enables saving from a few to a dozen or so percent of the fertilizer per hectare of farming area. It is worth noting that the technology provides direct access to NASA satellite observations, the European Space Agency and the European Commission (Copernicus program), as well as private operators. Thanks to the SatAgro application it is possible to monitor the development of crops, observe the effects of weather and agronomic operations, as well as draw conclusions from historical data [7]. 


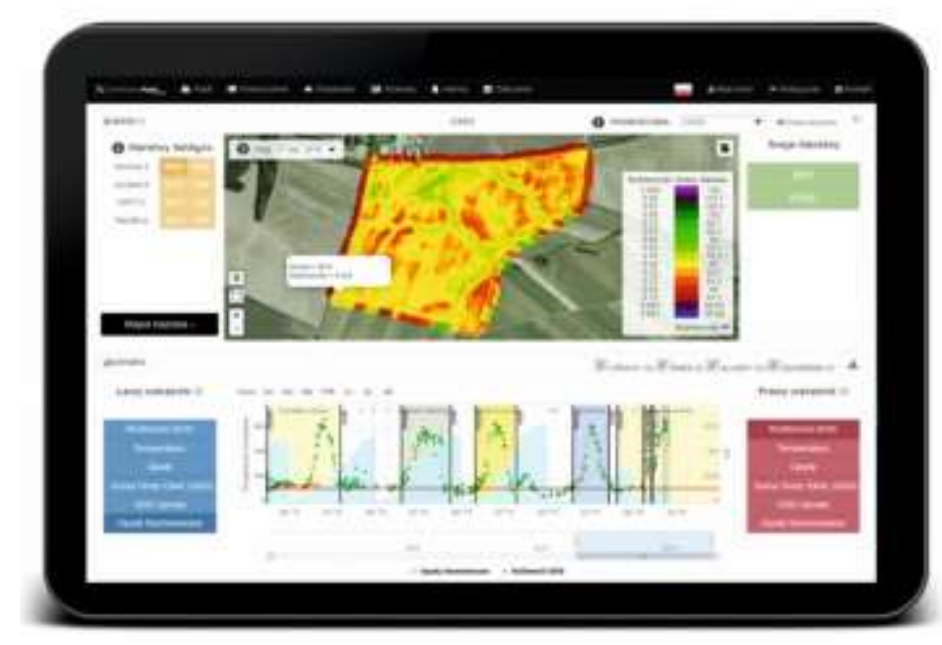

Fig. 5. SatAgro web application [5].

The Polish start-up, SatAgro, was created with the significant participation of Grupa Azoty, the largest Polish producer of mineral fertilizers [13]. The company occupies the second position in the European Union in the production of nitrogen and multicomponent fertilizers. The device that optimizes fertilization is also the $\mathrm{N}$-sensor. In this case, nitrogen fertilization is optimized depending on the condition and potential of the plantation and the state of their nutritional status (deficiency or excess of nitrogen is shown by the variable colour of the leaves). There are many products of this type; one of options available on the Polish market is CLAAS SENSOR ISARIA by CLAAS. CROP SENSOR is a tool for optimal application of not only nitrogen fertilizers and growth regulators, but also plant protection products. With regard to fertilization, the nitrogen dose is determined based on the size of biomass and the colour of the leaves (determined by chlorophyll content). Before starting the device, the operator enters the appropriate data - plant species, type of crop (fodder, bread), current development phase of plants, value of the pure ingredient in the fertilizer and expected yield [6]. Thanks to the device, the dosage of nitrogen fertilizer can be adapted to the needs of plants. Optical nitrogen sensors are offered not only by economic operators dealing with agricultural machines, but also producers of agrochemicals. A popular sensor on the Polish market (but also in Germany, Lithuania, Latvia and Estonia) is the YARA NSensor. Yara offers additionally a manual device for determining the nitrogen supply of plants (Yara N-Tester). There are also other system supporting tools mentioned in the literature.

An innovative idea regarding farmers' support in the field of plant protection was also presented in Poland by NEXBIO, which offers biotechnology solutions (DNA analysis). The DNA analyses carried out by NEXBIO allow very early detection of diseases of cultivated plants (even 1-5 months before their occurrence). This is because the technology used enables detecting even one cell of the micro-organism attacking 
the plant before the disease causes havoc in cultivation [3]. This makes it possible to make a decision about protection much earlier than in traditional support systems.

\section{Conclusion}

The variety of treatments in agricultural holdings in the field of application of agrochemicals requires from the agricultural producer to have knowledge in many fields, including agronomy, agrotechnics, mechanization, economics and law. The potential threat to the natural environment is important in the study; hence the systems supporting the farmer in making a rational decision in this area, along with the IT tools used for this purpose, are very important. To a large extent, it shortens the time of collecting and processing large amounts of data. The uncertainty in a farmer's decision regarding the use of agrochemicals should be particularly minimized.

On the basis of statistical data and own research, it should be emphasized that the level of using farmer support systems in the field of agrochemicals is insufficient. The word 'insufficient' does not refer only to the number of farms and the number of systems used in them. 'Insufficient' means not meeting social and environmental needs, due to the relatively high consumption of mineral fertilizers and herbicides in Poland. The modern, innovative systems presented in the article have been up to now used only to a small extent. The main obstacles are investment costs and the lack of appropriate skills. Nevertheless, the presented systems can contribute to the optimization of fertilization treatments and chemical protection of plants in agricultural holdings in Poland. This is important from the perspective of shaping low-emission agriculture in Poland, which is influenced, inter alia, by the scope of application of agrochemicals.

Acknowledgements. This study was conducted and financed in the framework of the research project "The state and prospects of the development of low-carbon agriculture in Poland and the behaviour of agricultural producers", granted by the National Science Centre in Poland, program SONATA, grant No. 2016/21/D/HS4/00087.

\section{References}

1. Adamski, A., Łozowicki, J., Kaczyński, P., Kalaji, H. M.: Ocena stanu zanieczyszczenia flory wodnej pozostałościami pestycydów na obszarach intensywnie użytkowanych rolniczo. Ecological Engineering, 19(3), 45-51 (2018).

2. Bramley, R. G. V., Ouzman, J.: Farmer attitudes to the use of sensors and automation in fertilizer decision-making: nitrogen fertilization in the Australian grains sector. Precision Agriculture, 1-19 (2018).

3. Nexbio. http://www.nexbio.pl/pl/uslugi-agronomiczne, URL, last accessed 2018/09/19.

4. Central Statistical Office. http://www.stat.gov.pl, URL, last accessed 2018/09/26.

5. Agrofoto Portal. https://www.agrofoto.pl, URL, last accessed 2018/09/20.

6. Ceny Rolnicze. https://www.cenyrolnicze.pl, URL, last accessed 2018/09/21.

7. Sat-agro. https://www.satagro.pl/?lang=pl\#start, URL, last accessed 2018/09/26. 
8. Lindblom, J., Lundström, C., Ljung, M.: Next Generation Decision Support Systems for Farmers: Sustainable Agriculture through Sustainable IT. The 11th European IFSA Symposium, 1-4 April 2014 in Berlin, Germany. IFSA, International Farming Systems Association-Europe Group. Vol. 1. IFSA Europe (2016).

9. Lindblom, J., Lundström, C., Ljung, M., Jonsson, A.: Promoting sustainable intensification in precision agriculture: review of decision support systems development and strategies. Precision Agriculture, 18(3), 309-331(2017).

10. Matthews, K. B., Schwarz, G., Buchan, K., Rivington, M., Miller, D.: Wither agricultural DSS? Computers and electronics in agriculture, 61(2), 149-159 (2008).

11. Piwowar, A.: Chemiczna ochrona roślin we współczesnym rolnictwie w perspektywie ekonomicznej i ekologicznej - korzyści, koszty oraz preferencje. Wyd. Uniwersytetu Ekonomicznego we Wrocławiu, Wrocław (2018).

12. Piwowar, A.: Opportunities and barriers to the development of Agriculture 4.0 in the context of low carbon agriculture in Poland. Double blind peer-reviewed proceedings part II. Of the International Scientific Conference Hradec Economic Days, vol. 8 (2), 169-178 (2018).

13. Piwowar, A., Realizacja koncepcji zrównoważonego rozwoju w produkcji agrochemikaliów. Metody, narzędzia i techniki zarządzania. Przemysł Chemiczny, 95 (4), 700-702 (2016). DOI: 10.15199/62.2016.4.2.

14. Piwowar, A.: The Consumption of Mineral Fertilizers and Herbicides in Poland Against the Background of the European Union. Problems of World Agriculture, 18(1), 194-202 (2018). DOI: 10.22630/PRS.2018.18.1.18.

15. Rose, D. C., Sutherland, W. J., Parker, C., Lobley, M., Winter, M., Morris, C., Twining S., Ffloulkes C., Amano T., Dicks, L. V.: Decision support tools for agriculture: Towards effective design and delivery. Agricultural Systems, 149, 165-174 (2016).

16. Rossi, V., Salinari, F., Poni, S., Caffi, T., Bettati, T.: Addressing the implementation problem in agricultural decision support systems: the example of vite. net ${ }^{\circledR}$. Computers and Electronics in Agriculture, 100, 88-99 (2014).

17. Rupnik, R., Kukar, M., Vračar, P., Košir, D., Pevec, D., Bosnić, Z.: AgroDSS: A decision support system for agriculture and farming. Computers and Electronics in Agriculture (2018).

18. Szymańska, J.: Gospodarowanie zasobami ziemi w Polsce - aspekty teoretyczne i praktyczne. Wyd. Uniwersytetu Ekonomicznego we Wrocławiu, Wrocław (2012).

19. Zalewski, A.: Rynek środków produkcji dla rolnictwa. Analizy Rynkowe, 45, 8-16 (2018).

20. Zalewski, A.: Sezonowość cen środków ochrony roślin w wybranych krajach Unii Europejskiej, Problemy Rolnictwa Światowego, 18 (XXXIII), 315-321(2018). 